\title{
Ex situ conservation of threatened native plants in Finland: analysis of the current status
}

\author{
Mari Miranto $^{1,3}$, Marko Hyvärinen ${ }^{1,3, *}$, Ritva Hiltunen ${ }^{1}$, Leif Schulman ${ }^{2}$ \\ ${ }^{1}$ Botanical Gardens, PO Box 3000, 90014 University of Oulu, Finland \\ ${ }^{2}$ Finnish Museum of Natural History, PO Box 17, 00014 University of Helsinki, Finland \\ ${ }^{3}$ Present address: Botany Unit, Finnish Museum of Natural History, PO Box 7, 00014 University of Helsinki, Finland
}

\begin{abstract}
Habitat destruction, invasive species, climate change and other threats to plant diversity are requiring increased conservation efforts. Priority is appropriately given to in situ conservation, but the important contribution that ex situ conservation can make is increasingly being recognised. In Finland, extensive seemingly intact natural areas have so far led authorities to consider ex situ conservation activities largely unnecessary. Botanic gardens, with estimated living collections of 80000 plant species worldwide, cultivate valuable plant material that can be used in recovery and reintroduction programmes. Recently, gardens all over the world have started to survey their collections. The results to date have revealed some very valuable collections but also highlighted inadequate databasing, narrow genetic representation and various genetic problems. As a part of an EU Life+ funded initiative, 4 Finnish botanic garden collections were investigated in order to find nationally threatened vascular plant species of known wild origin. Accessions were assessed for their potential use in future reintroduction programmes by ranking the quality of origin data and genetic intactness. Seventy-seven accessions from 56 vascular plant target taxa were found cultivated as living plants, representing $18 \%$ of Finland's nationally threatened taxa. The findings of this Finnish survey are similar to studies completed for botanic gardens elsewhere showing that there are deficiencies in intraspecific and within-population diversity. However, the accuracy of origin data and genetic intactness of the accessions were comparatively high. This survey forms the basis of the current development of a national plant ex situ action plan.
\end{abstract}

KEY WORDS: Biodiversity · Conservation • Botanic gardens · Convention on Biological Diversity · Genetic diversity $\cdot$ Living collection $\cdot$ Native plant species

Resale or republication not permitted without written consent of the publisher

\section{INTRODUCTION}

It has been estimated that human-induced changes in climate and habitat integrity place up to $50 \%$ of the world's plant species in danger of extinction (Pitman \& Jørgensen 2002, Root et al. 2003, Thuiller et al. 2005, Broadhurst \& Young 2007, Hahs et al. 2009). In Europe, the conservation status of more than half of the habitats and species listed in the Annexes of the EU Habitats Directive is classified as unfavourable, and the target of halting biodiversity loss by 2010 was not achieved (EEA 2009). In addition to the ecological, aesthetic and ethical consequences, loss of biodiversity and global warming pose a range of potential threats to human health, nutrition (Chivian \& Bernstein 2008) and economics (TEEB 2010).

Under these circumstances, plants protected ex $s i t u$, for instance in botanic garden collections, are increasingly important to supplement in situ conservation (Smith et al. 2003, Sarasan et al. 2006, Engelmann et al. 2007, Li \& Pritchard 2009). From ex situ collections, conserved in the form of living plants, stored seeds and tissue cultures, plants can be reintroduced to their original or, where necessary, eco- 
logically restored habitats (Cochrane et al. 2007, Guerrant \& Kaye 2007). Alternatively, new areas considered to provide more favourable living conditions as climate change proceeds can be targeted (McLachlan et al. 2007, Richardson et al. 2009).

Botanic gardens and their international collaborative organisation Botanic Gardens Conservation International (BGCI) have actively promoted the Global Strategy for Plant Conservation (GSPC; CBD 2002, 2010) by publishing a specific agenda for biodiversity conservation (Wyse Jackson \& Sutherland 2000) and several handbooks to guide its practical implementation in botanic gardens (e.g. Akeroyd \& Wyse Jackson 1995, Oldfield \& McGough 2007 , Hawkins et al. 2008). Botanic gardens participate in various conservation, reintroduction and restoration programmes (e.g. Vallee et al. 2004, Burney \& Burney 2007, Offord \& Meagher 2009, Trevor 2009). The study of living collections has contributed to the body of knowledge on threatened species (Norstog et al. 1986). Herbarium collections complemented by other data are used for predicting species response to climate change (Primack \& Miller-Rushing 2009) and for conservation planning (Peralvo et al. 2007).

However, the potentially great conservation value of the core resource of botanic gardens, the living collections with an estimated 80000 plant species (http://www.bgci.org) all over the world, is unfortunately often compromised by inadequate record keeping, narrow genetic representation and various genetic problems (e.g. Badley et al. 2004, Sharrock \& Jones 2009, Hällfors et al. 2010, Rae 2011). On the other hand, plant species globally extinct in the wild have been found in garden collections (Maunder et al. 1998, 2000), and the populations of some species have been restored from that source (Fraga et al. 1997). Hence, each botanic garden should thoroughly survey its collections to be able to develop their contents and quality so as to contribute maximally to the conservation of the world's flora.

In Finland, crop genetic resources are conserved under the National Plant Genetic Resources Programme (Veteläinen et al. 2008), but the protection of wild plants outside their natural habitats is in its infancy. This is largely due to the existence of extensive, seemingly intact natural and semi-natural areas in comparison to more fragmented landscapes in most other European countries. Still, the changing climate and the decline of valuable habitat types (Raunio et al. 2008, Normander et al. 2009, Auvinen et al. 2010) render it important to nationally evaluate the current situation and future needs for ex situ conservation of plants. Numerous plant species (e.g. the arctic so-called Primula sibirica group; Eurola 1999) occur in Finland at the edge of their total distribution area, and distinct subspecies or races can be distinguished for many widely distributed species (HämetAhti et al. 1998). Thus the notably poor Finnish native flora nevertheless provides invaluable genetic variation to the European flora as a whole (Lesica \& Allendorf 1995).

As part of an EU Life+ funded initiative 'Vulnerability Assessment of Ecosystem Services for Climate Change Impacts and Adaptation' (www.environment .fi/syke/vaccia), we surveyed the existing ex situ collections of nationally threatened vascular plant species in Finland. To assess the value of the accessions for eventual reintroduction programmes, the quality of data on origin and genetic intactness were evaluated. The results presented here form the basis for a national ex situ conservation action plan for native plants (Hyvärinen et al. 2011).

\section{MATERIALS AND METHODS}

\section{Focal institutions}

Collections of Finnish cultivars of crops and ornamentals are maintained in the Nordic Genetic Resource Center (NordGen, www.nordgen.org), and as field genebanks at Agrifood Research Finland (www.mtt.fi/english), and only to a lesser extent in botanic gardens. However, documented collections of native plant species are maintained on a large scale only in botanic gardens. Of the 11 botanic gardens in Finland (www.botanicgardens.fi), the Botanic Gardens of the Finnish Museum of Natural History (FMNH, located in Helsinki), the Botanical Gardens of the University of Oulu (UO), the Botanical Garden of the University of Turku (UTU), and the Botanic Garden of the University of Eastern Finland, Joensuu (UEF), were chosen to be investigated (Fig. 1). The remaining botanic garden collections were not analysed, because they possess plant material mainly of cultivated origin.

\section{Taxa of interest}

Of interest in the survey were 314 vascular plant taxa, which belong to 1 or several of the following groups:

(1) The IUCN Red List categories (www.iucnred list.org) Near Threatened, Vulnerable, Endangered, Critically Endangered and Regionally Extinct in 


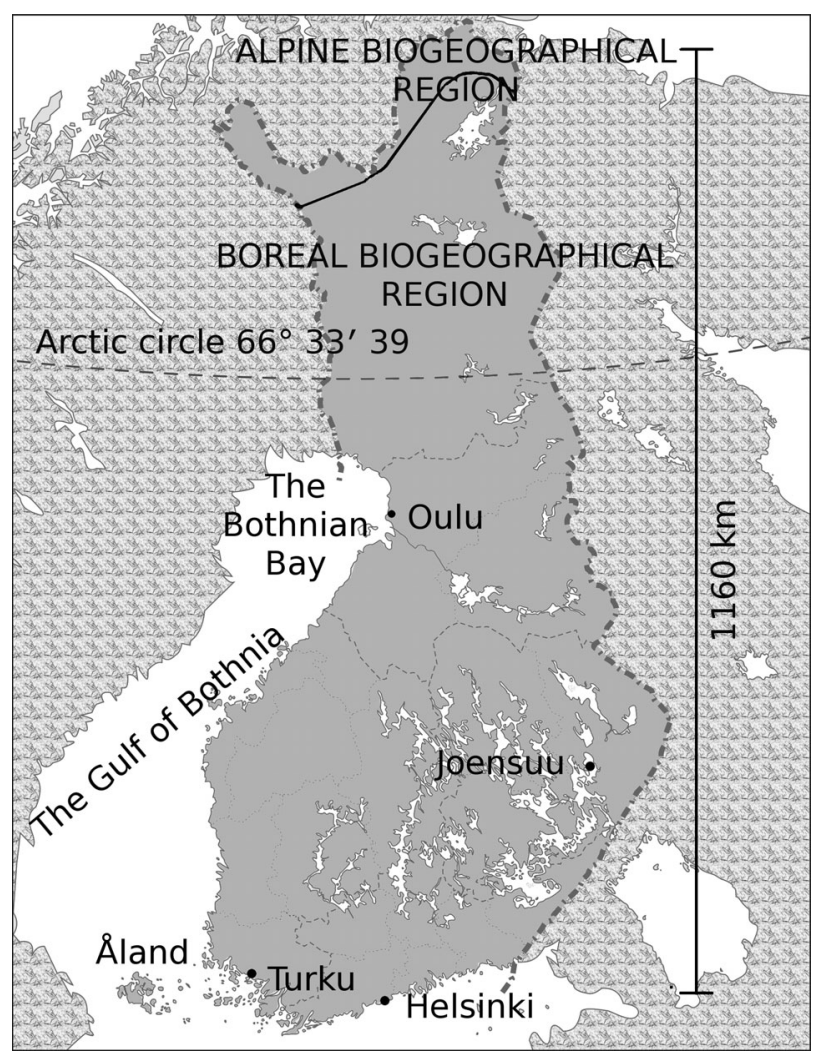

Fig. 1. Locations of the surveyed botanic gardens: Oulu (UO), Joensuu (UEF), Turku (UTU) and Helsinki (FMNH) (Original map Wikimedia commons, Public Domain, Author Mysid)

the Wild. The classification of Finnish taxa into these groups was taken from Rassi et al. (2001) and Rautiainen et al. (2002).

(2) The taxa mentioned in Annexes II and IV of the Habitats Directive (www.eur-lex.europa.eu).

(3) The vascular plants for which Finland is considered to be responsible (Rassi et al. 2001); for convenience, they are referred to as the 'responsibility species' in the current paper. The list compiled by Finnish botanists contains taxa endemic to Finland or northern Europe, taxa with most of the European stock found in Finland and taxa with disjunct occurrence and, thus, possible genetic differentiation.

(4) Taxa under strict protection by the Finnish Nature Conservation Decree (www.finlex.fi/en/). Picking or utilizing these taxa as well as destroying or damaging their habitats is prohibited.

(5) Taxa protected by law by the Finnish Nature Conservation Decree. Picking or utilizing these taxa is prohibited.

The species nomenclature follows Hämet-Ahti et al. $(1998,2005 a, b)$.

\section{Tracing unique accessions and assessing the accuracy of origin data and genetic intactness}

The database records of the botanic gardens were compared against the total list of 314 taxa of interest in order to find accessions of known Finnish wild origin. The accessions found were further investigated to trace cuttings and seeds donated from one garden to another, i.e. in fact representing the same accession. Collections from the same sites in different years were also traced and subsequently pooled.

The condition of the plants was checked during the summer 2009. In cases where separate accessions of the same taxon had formed mixed and inseparable stands in the field, these accessions were combined and treated as a single accession.

Botanic garden records range from unknown or cultivated origins to meticulous notes of collection sites in the wild. Accurate data on the origin are of great value to research and enable reintroduction to the same population in the habitat to which the ex situ plant material is adapted (Akeroyd \& Wyse Jackson 1995). In this study, only Finnish wild origin accessions were considered, and the accuracy of origin data was rated using 4 classes, 1 to 4 (Miranto 2005; Table 1).

Maintaining small numbers of individual plants in the absence of natural evolutionary processes predisposes plants to severe genetic depauperation by hybridisation; by adaptation to the garden environment through the die-off of plants with genotypes that do not suit these conditions although they may be fit in the wild; by genetic drift; and by inbreeding depression (Ashton 1987, Maunder et al. 2004, Ye et al. 2006, Kramer \& Havens 2009). This is undesirable, since population genetic diversity may have important ecological effects on community structure, primary productivity and fluxes of energy and nutrients (Crutsinger et al. 2006, Hughes et al. 2008), as well as in evolutionary processes. Therefore, the evaluation of ex situ conservation collections should include an evaluation of genetic intactness. In this study, the probability for hybridisation between species or genetically distinct populations was indicatively assessed using 3 classes, 1 to 3 (Table 1).

\section{RESULTS}

\section{Taxa cultivated ex situ in Finnish botanic gardens}

In total, 56 target plant taxa with 1 or several accessions of known wild Finnish origin were cultivated in Finnish botanic gardens. They belonged to 24 families, 
Table 1. Classes used to assess the accuracy of data on origin and genetic intactness

\begin{tabular}{ll}
\hline Class & Data on origin \\
\hline 1 & $\begin{array}{l}\text { The exact collection site, down to the level of a population/stand, can be found on the basis of the information } \\
2\end{array}$ \\
3 & $\begin{array}{l}\text { The collection area can be found, but the exact population/stand cannot be verified on the basis of the informa- } \\
\text { tion }\end{array}$ \\
& $\begin{array}{l}\text { The district or municipality of the collection site is known } \\
\text { Spontaneous, presumably from nearby wild habitats or introduced with other plants accessed into the botanic } \\
\text { garden. }\end{array}$ \\
Class & Genetic intactness \\
\hline 1 & $\begin{array}{l}\text { (a) Vegetative reproduction only; (b) agamospermic; (c) very distinctive species with easily distinguishable indi- } \\
\text { viduals (e.g. trees); (d) taxa with no other accessions of the same or closely related taxa grown in the garden; (e) } \\
\text { stored seeds, or (f) plantlets stored in vitro } \\
\text { (a) Big perennial herbaceous taxa growing in clearly delimited clumps even if accessions (same or related taxa) } \\
\text { of foreign, commercial, or unknown origin are grown in the garden; (b) annuals or perennial small herbaceous } \\
\text { taxa without clear clumps and other accessions (same or related taxa) of known Finnish (but no foreign, com- } \\
\text { mercial, or unknown origin) are cultivated in the garden } \\
\text { Small herbaceous annual or perennial taxa not growing in clearly delimited clumps, and accessions (same or } \\
\text { related taxa) of foreign, commercial or unknown origin are cultivated in the garden }\end{array}$ \\
3 &
\end{tabular}

most of which were represented by only 1 taxon. The most widely represented families were Caryophyllaceae (8 taxa), Ranunculaceae ( 7 taxa) and Poaceae (4 taxa). Three taxa (5\%) were annuals, 4 (7\%) were biennials or short-lived perennials (lifespan $<5$ yr), and the remaining $49(88 \%)$ were perennials. The taxa consisted of 9 woody plants (6 trees and shrubs, 1 liana, 1 semiwoody plant and 1 dwarf shrub), 4 pteridophytes and 43 herbaceous flowering plants. A complete list of the taxa and the accessions is given in Supplement available at www.int-res.com/articles/suppl/ n017p227_supp.pdf.

The 56 taxa represent $18 \%$ of the 314 taxa of interest in the survey. If only the taxa assigned an IUCN threat category Vulnerable, Endangered or Critically Endangered are considered, 26 out of $180(14 \%)$ are represented (Figs. 2 $\& 3)$. Seven taxa are mentioned in the Annexes of the Habitats Directive, 8 are under strict protection, 21 are 'responsibility species', and 21 plants are protected under the Nature Conservation Decree. The proportions compared to the total numbers in each group in Finland are shown in Fig. 3.

Each botanic garden hosted a unique selection of target taxa. Only 12 taxa (21\%) were found as living plants in 2 gardens, and none was found in more than 2 gardens. UO, the northernmost of the 4 gardens surveyed (Fig. 1), cultivated the largest collection of the taxa of interest (57 separate accessions within 42 taxa), and FMNH maintained the second largest collection (22 accessions, 18 taxa). UO and FMNH had distinct species compositions, whereas the smaller botanic gardens, UTU and UEF, had only very few accessions, as follows:

- UO specialises in northern boreal and alpine flora, and 'responsibility species' concentrated in the northern half of the country (e.g. Actaea erythrocarpa, Eriophorum brachyantherum, Polemonium acutiflorum). UO had taxa with only few sites in northern and eastern Finland (Silene tatarica, Gymnocarpium continentale, serpentine ecotypes of Minuartia biflora, Cerastium alpinum and Lychnis alpina)

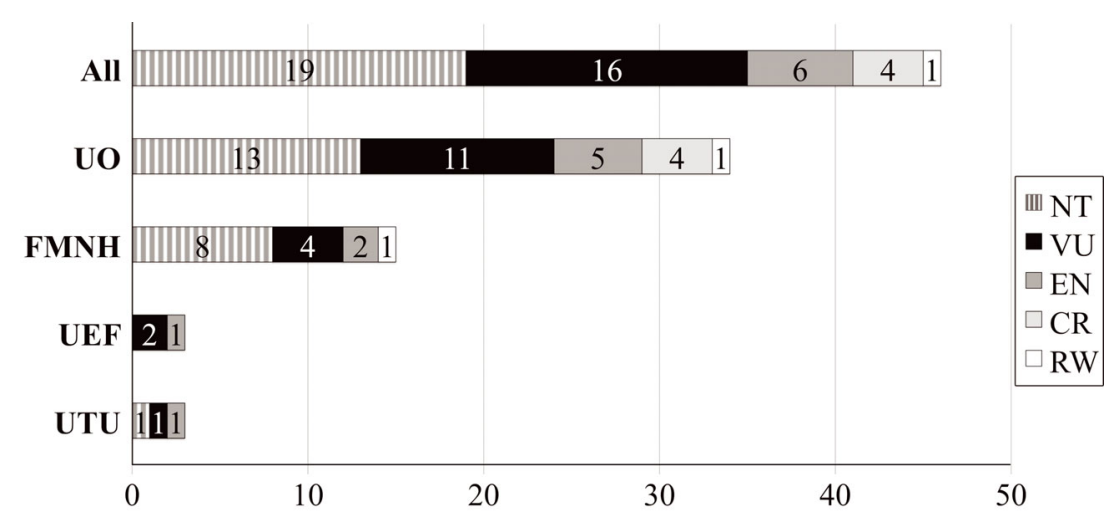

Fig. 2. Assignment of the plant taxa of interest in this study to the IUCN threat categories (NT: Near Threatened, VU: Vulnerable, EN: Endangered, CR: Critically Endangered, RW: Regionally Extinct in Wild). Numbers in the bars indicate how many taxa belong to each of the IUCN threat categories. Botanic garden abbreviations as in Fig. 1 


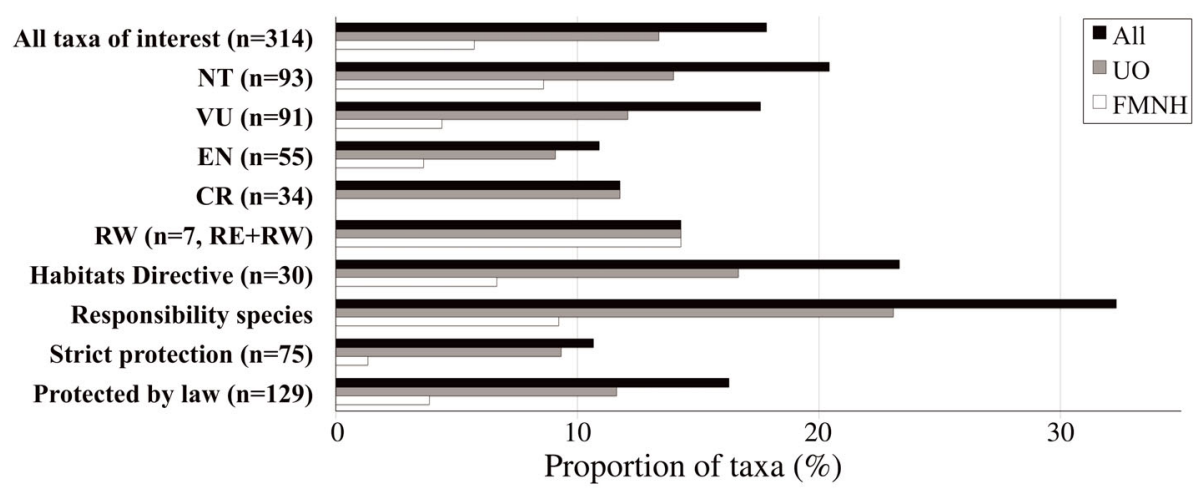

Fig. 3. Proportions of the taxa in each IUCN, European or Finnish conservation category found in all botanic gardens, and separately the Botanical Gardens of the University of Oulu (UO) and in the Botanic Garden of the Finnish Museum of Natural History $(\mathrm{FMNH})$. RE: regionally extinct, all other abbreviations as in Fig. 2. The bar RW indicates that the species is extinct in the wild but safe in cultivation compared to regionally extinct ones
- UO also had plants occurring as rare in the Bothnian Bay area (Artemisia campestris subsp. bottnica, Primula nutans subsp. finmarchica var. jokelae), and the alpine-arctic Erigeron borealis was represented

- FMNH grew several accessions of southern Ulmus glabra and U. laevis, and of Taxus baccata, whose natural distribution in Finland is restricted to the Åland Islands between Finland and Sweden

- FMNH also had southern and south-western seashore plants, such as Leersia oryzoides and Mentha aquatica var. litoralis

- In UEF, the target taxa were represented by only 3 living accessions, all of which were replicated in UO, but some additional orchid material salvaged from a newly established gold mine is cultivated in vitro on the premises of the Faculty of Forest Sciences of the University of Eastern Finland, Joensuu (H. Vanhanen pers. comm.)

- The 4 unique accessions maintained in UTU contributed with valuable material of Rosa sherardii.

\section{Quantity and quality of accessions}

Initially, 118 live accessions belonging to the taxa of interest were identified. However, after crosschecking for (1) plant material that originated from the same sites and had been propagated and transferred between gardens, and (2) material collected from the same sites in different years, the number of separate accessions diminished by 41 to 77 (65\% of the initial number of accessions). In 7 taxa (13\%), temporally replicated collections from the same sites were identified. Eight taxa (14\%) had multiple accessions resulting from the distribution of seed or clonal plant material from one botanic garden to another and for 5 taxa (9\%) 2 to several accessions were so badly intermingled where they were growing that they were no longer separable.
Intraspecific diversity of the collections was low. In most cases (44 taxa, $79 \%$ ), there was only 1 accession per taxon. Under 11 taxa there were 2 or 3 separate accessions, and 1 near threatened taxon was represented by 6 accessions. In 8 cases of the 12 taxa shared between gardens, plants were of the same provenance. All target taxon accessions comprised 1 or only a few individuals.

The accuracy of origin and genetic intactness were high, the most common grade for both being 1 (Fig. 4). For 16 accessions (20\%), both grades were 1 , i.e. the exact collection site was recorded down to the population/stand level, and the risk of hybridisation between accessions of the same or related taxa was assessed as very low. Sixteen accessions $(20 \%)$ were evaluated to be 'very likely to be' hybrids with plants of foreign, unknown or commercial origin of the same or a related taxon. When comparing the different botanic gardens, the genetic intactness was most compromised in UO, partly due to the greatest number of the taxa of interest from both native and other origins. A northern 'responsibility subspecies', Thymus serpyllum subsp. tanaënsis in FMNH typified the problem of systematically arranged collections in botanic gardens. It was grown in the same flowerbed as the other sub-
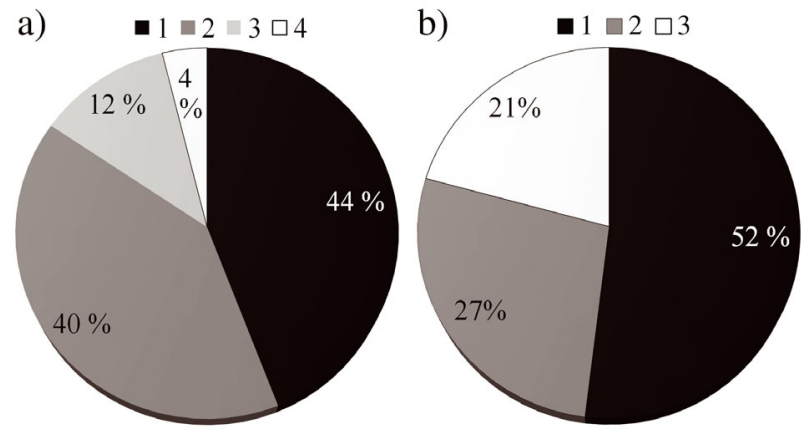

Fig. 4. Frequencies of each class of taxa (1 to 4) of interest for (a) origin data and (b) genetic intactness. See Table 1 for definition of each class 
species $T$. serpyllum subsp. serpyllum and also $T$. pulegioides, all capable of hybridisation with each other. Moreover, due to the creeping habit and the stems that produce axillary roots, both subspecies of $T$. serpyllum were severely intermingled.

The standard of record keeping varied markedly among the surveyed botanic gardens, from meticulously recorded and backed-up origin and propagation data to deficient or completely lost information. Herbarium specimens or photos of the garden's plants were sporadically stored in FMNH and UO, but not at all in UTU and UEF. In all gardens, only 1 species was found to be incorrectly identified.

\section{Additional plant material stored as seeds and in vitro}

In addition to the living plants, 58 seed and 4 in vitro accessions of the taxa of interest were found, representing a further 52 separate accessions within 17 taxa (9 new taxa). Seven provenances present as living plants also existed as seeds, 2 also as in vitro plantlets, and 1 as all 3 forms. Salicornia europaea was found only in vitro, but since the in vitro protocol for that species is not yet fully established, its future is uncertain. Seeds were stored in varying conditions that did not meet the internationally approved standards (FAO/IPGRI 1994, ENSCONET 2009). Typically seeds were contained in paper bags at $+5^{\circ} \mathrm{C}$ in ambient humidity, with several collections dating back to the 1980 s, so viability may be low. The seeds were nonetheless sown as student practical work in the micropropagation laboratory, so new plant material will possibly be added to the results of the current survey.

\section{DISCUSSION}

The conservation value of the ad hoc botanic garden collections is rather variable. The results presented here partly match the outcomes of similar studies carried out for other botanic gardens, showing deficiencies in intraspecific and withinpopulation diversity and in record keeping (Maunder et al. 2001a,b, Radford et al. 2003, Badley et al. 2004, Frachon et al. 2005, Yukawa 2006, Sharrock \& Jones 2009, Hällfors et al. 2010). For the Finnish gardens we surveyed, we found that most taxa were represented by a single accession consisting of 1 or few individuals. Furthermore, small numbers of plants per accession and the lack of duplicates in another garden and, to a lesser extent, deficient recording and sharing of cultivation expertise, had resulted in losses of several valuable taxa that were recorded in previous national botanic garden surveys (Väre \& Siuruainen 1994, Hansen 2000). Missing origin data eliminated from the survey a number of threatened taxa cultivated in UEF and UTU, and replicated plant material originating from the same sites, albeit labelled with different accession numbers, notably complicated the study.

However, as in a study evaluating Saintpaulia collections in European botanic gardens (Miranto 2005, Schulman \& Miranto 2006), the current study showed less sharing of accessions between gardens and better knowledge of origins than expected. All in all, 77 valuable accessions within 56 taxa were found, although most of the plants were originally acquired without any special conservation initiative in mind. The origin of the accessions was accurately known ( $84 \%$ of the living accessions with class 1 or 2 ), and their level of hybridisation was indicatively assessed low $(79 \%$ of the living accessions with class 1 or 2 ).

It is essential to define the present state of the collections to be able to measure the progress in reaching Target 8 of the GSPC ('At least 75 per cent of threatened plant species in ex situ collections, preferably in the country of origin, and at least 20 per cent available for recovery and restoration programmes'; CBD 2010). Consequently, several botanic gardens have recently surveyed their collections of living plants, stored seeds or in vitro plantlets (e.g. Hyvärinen et al. 2010), and a regional survey was conducted by BGCI to find out the current state of ex situ conservation of those European plants that are threatened throughout their range (Sharrock \& Jones 2009). Moreover, special challenges caused by climate change have been identified and action plans for botanic gardens compiled to tackle these issues (ANBG 2008, Wyse Jackson 2008, Godefroid \& Vanderborght 2010, Monteiro-Henriques \& EspíritoSanto 2011). Moreover, collection policies of botanic gardens all over the world are currently being developed and revised partly in response to the Targets of GSPC. In Finland, FMNH has got a new as yet unpublished collection policy, and other gardens are planning to develop policies in the near future.

Comparing the results of different surveys is complicated by the lack of a definition of what constitutes a plant species that is safely protected ex situ. Target 8 of the GSPC (CBD 2010) does not specify how accurately the origin of an accession should be known or to what extent ex situ collections of a particular species should be representative of the genetic diversity of that species to be regarded as conserved ex situ 
(CBD 2009). Thus, the collections referred to as being conserved ex situ do not necessarily hold the associated provenance, ecological and conservation information on the species, which nevertheless would be essential for successful recovery and restoration programmes. For instance, in their study of the 'ad hoc' collections of threatened plants in the Royal Botanic Gardens Edinburgh, Radford et al. (2003) concluded that $80 \%$ of the accessions were of little immediate use to conservation programmes, because they were not of known wild origin and their genetic base was inadequate. Furthermore, less than half of the target group identified on the basis of a database was actually found alive in the collections.

As recommended in the European Strategy for Plant Conservation (Planta Europa 2008), any assessment of ex situ collections of threatened species should preferably include an assessment of the genetic diversity of the species held, and additional accessions should be collected where necessary. In practice, however, little information is available on whether most existing ex situ collections, and reintroductions made from them, are genetically representative, and the few studies published on the subject indicate reduced genetic variation and biased genetic composition in these artificial populations (Ibáñez et al. 1999, Koch \& Bernhardt 2004, Li et al. 2005, Ruci ska \& Puchalski 2011). In the current study, made possible through additional external funding, it was feasible to meticulously evaluate the accuracy of origin data and indicatively assess the genetic intactness of the accessions. For more accurate genetic information, molecular studies should be carried out.

BGCI produces a considerable amount of information with recommendations about plant collection maintenance and documentation, but in many gardens these are not implemented due to limited resources (Badley et al. 2004). Conservation competes with other aims of botanic gardens, and too many initiated projects are left aside when temporary funding ends and the person responsible for the project is forced to move to other duties. Also in Finnish botanic gardens, funding constraints hamper ex situ conservation activities. Hence, if extra funding for ex situ conservation is not available, alternative approaches that are not completely reliant on external project money should be found. The gardens should at least safeguard their existing valuable collections and each one concentrate on a few additional threatened taxa that are best suited to the local climatic conditions (Väre \& Siuruainen 1994, cf. PlantNetwork Target 8, www.plantnetwork.org).
No botanic garden can effectively act alone if aiming to include the ideal of at least 50 unique accessions per taxon in ex situ collections (Marshall \& Brown 1975, Brown \& Briggs 1991). It is therefore essential to establish links with other gardens and institutions growing these taxa, for the exchange of pollen and/or seeds as well as for propagation information (Maunder et al. 2001a). An ex situ conservation activity distributed in several institutions also enables diverse cultivation of large plant species requiring more space. In Finland, however, no formal procedure exists to steer the development of a division of labour between botanic gardens. Each garden is part of a university, and its main duty is to serve the needs of the parent organisation's research and teaching, whereas national ex situ conservation remains a byproduct of the other activities, rather than a prioritised and coordinated activity in its own right. To strengthen the contribution of Finnish gardens to ex situ conservation, a national cooperation body in this area should be established, preferably under the steering of the Ministry of the Environment.

In the face of climate change and rapid biodiversity loss, the various aims of each garden should be prioritised (Aplin et al. 2007) and conservation maximised per Euro spent (Griffith \& Husby 2010). Some gardens may be over-ambitious with the number of plants in their care for the resources they have, or for changed economic circumstances, and they should revise their programmes to maintain smaller collections to a higher standard (Maunder et al. 2001a, Hällfors et al. 2010). In some cases, the number of botanic gardens within a country should be reevaluated and the restricted resources concentrated in a few gardens with carefully considered areas of specialisation. These questions need to be seriously addressed in the coming years.

Acknowledgements. This study was supported by the EU Life+ programme and by the grant awarded to M.M. by the Finnish Cultural Foundation. We thank anonymous reviewers for relevant suggestions to improve earlier versions of this manuscript. The staffs of the botanic gardens in Oulu, Helsinki, Turku and Joensuu are acknowledged for their invaluable help during the survey.

\section{LITERATURE CITED}

Akeroyd J, Wyse Jackson P (eds) (1995) A handbook for botanic gardens on the reintroduction of plants to the wild. Botanic Gardens Conservation International, Richmond

ANBG (Australian National Botanic Gardens) (2008) National strategy and action plan for the role of Australia's botanic gardens in adapting to climate change. Australian National Botanic Gardens, Canberra 
Aplin D, Linington S, Rammeloo J (2007) Indices seminum: Are they really worth the effort? Sibbaldia 5:93-107

Ashton PS (1987) Biological considerations in in situ vs ex situ plant conservation. In: Bramwell D, Hamann O, Heywood V, Synge $H$ (eds) Botanic gardens and the World Conservation Strategy. Academic Press, London, p 117-130

Auvinen AP, Kemppainen E, von Weissenberg M (eds) (2010) Fourth national report on the implementation of the Convention on Biological Diversity in Finland. Ministry of the Environment, Helsinki

Badley C, Hill D, Wray N (2004) Inadequate accession data compromises the conservation value of plant collections. Sibbaldia 2:5-19

Broadhurst L, Young A (2007) Seeing the wood and the trees - predicting the future for fragmented plant populations in Australian landscapes. Aust J Bot 55:250-260

Brown AHD, Briggs JD (1991) Sampling strategies for genetic variation in ex situ collections of endangered plant species. In: Falk DA, Holsinger KE (eds) Genetics and conservation of rare plants. Oxford University Press, New York, NY, p 99-119

Burney DA, Burney LP (2007) Paleoecology and 'inter-situ' restoration on Kaua i, Hawai`i. Front Ecol Environ 5: 483-490

CBD (Convention on Biological Diversity) (2002) Global strategy for plant conservation. Secretariat of the Convention on Biological Diversity, Montreal

CBD (2009) The convention on biological diversity plant conservation report: a review of progress in implementing the Global Strategy of Plant Conservation (GSPC). Secretariat of the Convention on Biological Diversity, Montreal

CBD (2010) COP 10 Decision X/17. Consolidated update of the Global Strategy for Plant Conservation 2011-2020. Available at www.cbd.int/decision/cop/?id=12283

Chivian E, Bernstein A (eds) (2008) Sustaining life: how human health depends on biodiversity. Oxford University Press, New York, NY

Cochrane JA, Crawford AD, Monks LT (2007) The significance of ex situ conservation to reintroduction of threatened plants. Aust J Bot 55:356-361

Crutsinger GM, Collins MD, Fordyce JA, Gompert Z, Nice CC, Sanders NJ (2006) Plant genotypic diversity predicts community structure and governs an ecosystem process. Science 313:966-968

EEA (European Environment Agency) (2009) Progress towards the European 2010 biodiversity target. EEA Report No 4/2009. European Environment Agency, Copenhagen

Engelmann F, Dulloo ME, Astorga C, Dussert S, Anthony F (eds) (2007) Complementary strategies for ex situ conservation of coffee (Coffea arabica L.) genetic resources. A case study in CATIE, Costa Rica. Topical reviews in Agricultural Biodiversity. Bioversity International, Rome

ENSCONET (European Native Seed Conservation Network) (2009) ENSCONET curation protocols and recommendations. European Native Seed Conservation Network. Available at www.plants2020.net/document/0184

Eurola S (1999) Kasvipeitteemme alueellisuus (Biogeography of Finnish plants). Oulanka Reports 22. University of Oulu, Oulu

FAO/IPGRI (Food and Agriculture Organization of the United Nations/International Plant Genetic Resources
Institute) (1994) Genebank standards. Food and Agriculture Organization of the United Nations and International Plant Genetic Resources Institute, Rome

Frachon N, Jebb M, Rae D (2005) Plantnetwork's Target 8 project - the survey stages. Sibbaldia 3:67-82

Fraga P, Vicens MM, Gradaille JLL (1997) Re-introduction of Lysimachia minoricensis (Primulaceae) in Minorca, Balearic Islands. Re-introduction News 13:12-13

Godefroid S, Vanderborght T (2010) Seed banking of endangered plants: Are we conserving the right species to address climate change? Biodivers Conserv 19: 3049-3058

Griffith P, Husby C (2010) The price of conservation: measuring the mission and its cost. BGjournal 7:12-14

Guerrant EO Jr, Kaye TN (2007) Reintroduction of rare and endangered plants: common factors, questions and approaches. Aust J Bot 55:362-370

Hahs AK, McDonnell MJ, McCarthy MA, Vesk PA and others (2009) A global synthesis of plant extinction rates in urban areas. Ecol Lett 12:1165-1173

Hällfors M, Schulman L, Lindén L, Rita H (2010) Testing bioclimatic hypotheses with botanic garden collectionscuratorial considerations. In: Proc 4th Glob Bot Gardens Congr. Available at www.bgci.org/files/Dublin2010/ papers/Hällfors-Maria.pdf

Hämet-Ahti L, Suominen J, Ulvinen T, Uotila P (eds) (1998) Retkeilykasvio (Field flora of Finland). Finnish Museum of Natural History, Botanical Museum, Helsinki

Hämet-Ahti L, Kurtto A, Lampinen R, Piirainen M and others (2005a) Lisäyksiä ja korjauksia Retkeilykasvion neljänteen painokseen (Additions and corrections to the fourth edition of Field flora of Finland). Lutukka 21: $41-85$

Hämet-Ahti L, Kurtto A, Lampinen R, Piirainen M and others (2005b) Lisäyksiä ja korjauksia Retkeilykasvion neljänteen painokseen. Jälkimmäinen osa: auktoreita ja synonyymejä. (Additions and corrections to the fourth edition of Field flora of Finland: auctors and synonyms). Lutukka 21:109-116

Hansen A (2000) Kasvitieteelliset puutarhat ja ex situ - suojelu (Botanic gardens and ex situ conservation). MSc thesis, University of Oulu

Hawkins B, Sharrock S, Havens K (2008) Plants and climate change: Which future? Botanic Gardens Conservation International, Richmond

> Hughes AR, Inouye BD, Johnson MTJ, Underwood N, Vellend $M$ (2008) Ecological consequences of genetic diversity. Ecol Lett 11:609-623

Hyvärinen M, Tamm H, Sild J (2010) Ex situ plant conservation in botanic gardens around the Baltic Sea. Conference on Strategies and development of botanic gardens around the Baltic Sea 30 September to 3 October 2010, Tartu (Abstract)

Hyvärinen M, Miranto M, Hiltunen R, Schulman L (2011) Strategy and action plan for ex-situ conservation of threatened plants in Finland-Action 11: assessment of the impacts of climate change on biodiversity in coastal ecosystems and the implementation of new policies and conservation strategies. Available at www.ymparisto.fi/ download.asp? contentid=132157\&lan=fi

> Ibáñez CC, Mayol M, Rosselló JA (1999) Isozyme uniformity in a wild extinct insular plant, Lysimachia minoricensis J.J. Rodr. (Primulaceae). Mol Ecol 8:813-817

Koch M, Bernhardt KG (2004) Cochlearia macrorrhiza, a highly endangered lowland species from Eastern Aus- 
tria. Conservation genetics, ex situ and in situ conservation efforts. Scr Bot Belg 29:157-164

Kramer AT, Havens K (2009) Plant conservation genetics in a changing world. Trends Plant Sci 14:599-607

> Lesica P, Allendorf FW (1995) When are peripheral populations valuable for conservation? Conserv Biol 9:753-760

> Li DZ, Pritchard HW (2009) The science and economics of ex situ plant conservation. Trends Plant Sci 14:614-621

Li YY, Chen XY, Zhang X, Wu TY, Lu HP, Cai YW (2005) Genetic differences between wild and artificial populations of Metasequoia glyptostroboides: implications for species recovery. Conserv Biol 19:224-231

Marshall DR, Brown AHD (1975) Optimum sampling strategies in genetic conservation. In: Frankel OH, Hawkes JG (eds) Crop genetic resources for today and tomorrow. Cambridge University Press, Cambridge, p 53-80

Maunder M, Higgens S, Culham A (1998) Neither common nor garden: the garden as a refuge for threatened plant species. Curtis's Bot Mag 15:124-132

> Maunder M, Culham A, Alden B, Zizka G and others (2000) Conservation of the toromiro tree: case study in the management of a plant extinct in the wild. Conserv Biol 14: $1341-1350$

Maunder M, Higgens S, Culham A (2001a) The effectiveness of botanic garden collections in supporting plant conservation: a European case study. Biodivers Conserv 10:383-401

> Maunder M, Lyte B, Dransfield J, Baker W (2001b) The conservation value of botanic garden palm collections. Biol Conserv 98:259-271

Maunder M, Hughes C, Hawkins JA, Culham A (2004) Hybridization in ex situ plant collections: conservation concerns, liabilities, and opportunities. In: Guerrant EO, Havens K, Maunder M (eds) Ex situ plant conservation: supporting species survival in the wild. Island Press, Washington, DC, p 325-364

McLachlan JS, Hellman JJ, Schwartz MW (2007) A framework for debate of assisted migration in an era of climate change. Conserv Biol 21:297-302

Miranto M (2005) Living collections of botanic gardens as a means of ex situ conservation - a case study of African violets (Saintpaulia) in Europe. M.Sc. thesis, University of Helsinki. Available at www.ethesis.helsinki.fi/ julkaisut/bio/bioja/pg/miranto/

Monteiro-Henriques T, Espírito-Santo MD (2011) Climate change and the outdoor living plant collections: an example from mainland Portugal. Biodivers Conserv 20: 335-343

Normander B, Levin G, Auvinen A, Bratli H and others (2009) State of biodiversity in the Nordic countries: an assessment of progress towards achieving the target of halting biodiversity loss by 2010. TemaNord 509. Nordic Council of Ministers, Copenhagen

Norstog KJ, Stevenson DW, Niklas KJ (1986) The role of beetles in the pollination of Zamia furfuracea L. fil. (Zamiaceae). Biotropica 18:300-306

Offord CA, Meagher PF (eds) (2009) Plant germplasm conservation in Australia: strategies and guidelines for developing, managing and utilising ex situ collections. Australian Network for Plant Conservation in partnership with Australian Seed Conservation and Research (AuSCaR), Canberra

Oldfield S, McGough N (comps) (2007) A CITES manual for botanic gardens. Botanic Gardens Conservation International, Richmond
Peralvo M, Sierra R, Young KR, Ulloa-Ulloa C (2007) Identification of biodiversity conservation priorities using predictive modeling: an application for the equatorial pacific region of South America. Biodivers Conserv 16:2649-2675

Pitman NC, Jørgensen PM (2002) Estimating the size of the world's threatened flora. Science 298:989

Planta Europa (2008) A sustainable future for Europe; the European strategy for plant conservation 2008-2014. Plantlife International, Salisbury and the Council of Europe, Strasbourg

Primack RB, Miller-Rushing AJ (2009) The role of botanical gardens in climate change research. New Phytol 182: 303-313

Radford E, Dossman M, Rae D (2003) The management of 'ad hoc' ex situ conservation status species at the Royal Botanic Garden Edinburgh: a review of options. Sibbaldia 1:43-80

Rae D (2011) Fit for purpose: the importance of quality standards in the cultivation and use of live plant collections for conservation. Biodivers Conserv 20:241-258

Rassi P, Alanen A, Kanerva T, Mannerkoski I (eds) (2001) Suomen lajien uhanalaisuus (The Red List of Finnish Species). Ministry of the Environment \& Finnish Environment Institute, Helsinki

Raunio A, Schulman A, Kontula T (2008) Suomen luontotyyppien uhanalaisuus (Assessment of threatened habitat types in Finland). Finnish Environment Institute, Helsinki

Rautiainen V, Ryttäri T, Kurtto A, Väre H (eds) (2002) Putkilokasvien uhanalaisuuden arviointi-lajikohtaiset perustelut (Threat assessment of vascular plants in Finland - the species documentation). Finnish Environment Institute, Helsinki

Richardson DM, Hellman JJ, McLachlan JS, Sax DF and others (2009) Multidimensional evaluation of managed relocation. Proc Natl Acad Sci USA 106:9721-9724

Root TL, Price JT, Hall KR, Schneider SH, Rosenzweig C, Pounds JA (2003) Fingerprints of global warming on wild animals and plants. Nature 421:57-60

Rucińska A, Puchalski J (2011) Comparative molecular studies on the genetic diversity of an ex situ garden collection and its source population of the critically endangered polish endemic plant Cochlearia polonica E. Fröhlich. Biodivers Conserv 20:401-413

Sarasan V, Cripps R, Ramsay MM, Atherton C, McMichen M, Prendergast G, Rowntree JK (2006) Conservation in vitro of threatened plants - progress in the past decade. In Vitro Cell Dev Biol Plant 42:206-214

Schulman L, Miranto M (2006) Living collections of botanic gardens as a means of ex situ conservation-a case study of African violets. In: Hanzelka P (ed) EuroGard IV. Botanic gardens and the 2010 challenge. Congress proceedings. Czech Botanic Garden Union, PraguePruhonice. Available at www.bgci.org/resource/eurogard _proceedings/?

Sharrock S, Jones M (2009) Europe's threatened plants: progress towards Target 8 of the Global Strategy for Plant Conservation. Botanic Gardens Conservation International, Richmond

Smith RD, Dickie JB, Linington SH, Pritchard HW, Probert RJ (eds) (2003) Seed conservation: turning science into practice. Kew Publishing, London

TEEB (The Economics of Ecosystems and Biodiversity) (2010) The economics of ecosystems and biodiversity: mainstreaming the economics of nature; a synthesis of 
the approach, conclusions and recommendations of TEEB. Progress Press, Malta

Thuiller W, Lavorel S, Araújo MB, Sykes MT, Prentice IC (2005) Climate change threats to plant diversity in Europe. Proc Natl Acad Sci USA 102:8245-8250

Trevor A (2009) Kirstenbosch National Botanic Garden: threatened plants programme and capacity building. In: Lehvävirta S, Aplin D, Schulman L (eds) Botanic gardens in the age of climate change-programme, abstracts, and delegates, EuroGard V, Ulmus 13. Helsinki University Botanic Garden, Helsinki, p 34

Vallee L, Hogbin T, Monks L, Makinson B, Matthes M, Rossetto $M$ (2004) Guidelines for the translocation of threatened plants in Australia, 2nd edn. Australian Network for Plant Conservation, Canberra

Väre H, Siuruainen M (1994) Uhanalaisia kasveja Suomen kasvitieteellisiin puutarhoihin? (Threatened plants and botanical gardens - a field of possibilities.). Aquilo Ser Bot 33:173-178

Editorial responsibility: Raymond Tremblay,

Humacao, Puerto Rico
Veteläinen M, Huldén M, Pehu T (2008) State of plant genetic resources for food and agriculture in Finland. Second Finnish national report. Ministry of Agriculture and Forestry, Helsinki

Wyse Jackson P (2008) The potential impact of climate change on native plant diversity in Ireland. National Botanic Gardens of Ireland. Available at www.botanic gardens.ie/news/20080122.htm (accessed 14 April 2011)

Wyse Jackson PS, Sutherland LA (2000) International agenda for botanic gardens in conservation. Botanic Gardens Conservation International, Richmond

Ye QG, Yao XH, Zhang SJ, Kang M, Huang HW (2006) Potential risk of hybridization in ex situ collections of two endangered species of Sinojackia hu (Styracaceae). J Integr Plant Biol 48:867-872

Yukawa T (2006) Status of ex situ conservation of threatened Japanese plant species in Japanese botanic gardens. BGjournal 3:16-17

Submitted: October 17, 2011; Accepted: March 08, 2012 Proofs received from author(s): May 11, 2012 